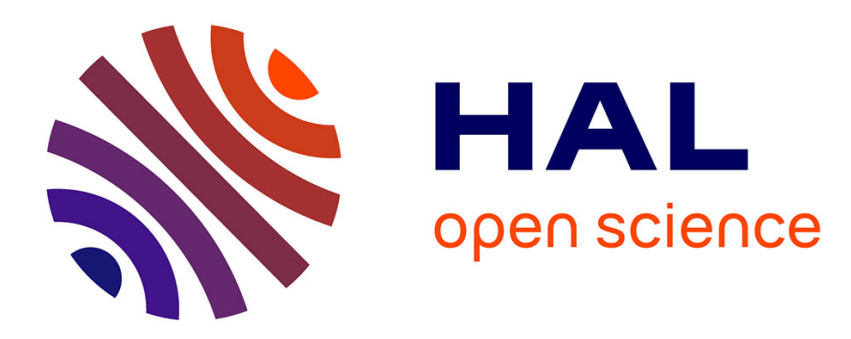

\title{
ACTIVE MODE-LOCKING OF A DIODE-PUMPED Ce, Nd: YAG
}

C. Eckert, B. Cunin, J. Miehe

\section{To cite this version:}

C. Eckert, B. Cunin, J. Miehe. ACTIVE MODE-LOCKING OF A DIODE-PUMPED Ce, Nd: YAG. Journal de Physique IV Proceedings, 1991, 01 (C7), pp.C7-303-C7-306. 10.1051/jp4:1991781 . jpa00251024

\section{HAL Id: jpa-00251024 https://hal.science/jpa-00251024}

Submitted on 1 Jan 1991

HAL is a multi-disciplinary open access archive for the deposit and dissemination of scientific research documents, whether they are published or not. The documents may come from teaching and research institutions in France or abroad, or from public or private research centers.
L'archive ouverte pluridisciplinaire HAL, est destinée au dépôt et à la diffusion de documents scientifiques de niveau recherche, publiés ou non, émanant des établissements d'enseignement et de recherche français ou étrangers, des laboratoires publics ou privés. 


\section{ACTIVE MODE-LOCKING OF A DIODE-PUMPED Ce, Nd: YAG}

C. ECKERT, B. CUNIN and J.A. MIEHE

Groupe d'Optique Appliquée, Centre de Recherches Nucléaires, 23 rue du Loess, F-67037 Strasbourg cedex, France

ABSTRACT : We have developped a mode-locked Ce,Nd:YAG laser end-pumped by a $500 \mathrm{~mW}$ laser diode. With a short cavity configuration the $\mathrm{cw}$ optical output power was $155 \mathrm{~mW}$, which corresponds to an optical efficiency of $30.9 \%$ and an electrical efficiency of $9.5 \%$. A cavity length extended to $1.4 \mathrm{~m}$ allows mode -locked operation at $106 \mathrm{MHz}$ and pulses widthes of 150 ps have been obtained with an average power of $23 \mathrm{~mW}$.

We describe Ce,Nd:YAG and Nd:YAG lasers end-pumped by a $500 \mathrm{~mW}$ laser diode (SDL-2432-H1) monted on a thermoelectric cooler used to adjust the diode array emission wavelength to the absorption peak of the crystal. The diode output is collimated by a $6.5 \mathrm{~mm}$ focal length lens (Melles Griot 06GLC001/D), made approximately circular by passing through an anamorphic beam expander (Melles Griot 06GPA002), and then focused on the 1 aser rod by a $25.6 \mathrm{~mm}$ focal length lens (Melles Griot 06GLC004). With this coupling optics, a spot diameter smaller than 130 um can be produced with about $10 \%$ power loss. The Ce, Nd:YAG rod is $5 \mathrm{~mm}$ in 1 ength and $5 \mathrm{~mm}$ in diameter, and the Nd:YAG rod is $10 \mathrm{~mm}$ in length and $3 \mathrm{~mm}$ in diameter, both with planar ends. The pumped end of the rods is dielectrically coated to be of high transmission at the pump wavelength of $810 \mathrm{~nm}$ and high reflection at the lasing wavelength of $1.064 \mu \mathrm{m}$, so that this end acts as cavity input mirror. The other face is antireflection coated at $1.064 \mu \mathrm{m}$. 
In a first attempt we developped a short cavity setup (fig.1a) in order to test the rods. In this configuration, an output mirror of $20 \mathrm{~cm}$ radius of curvature was placed about $10 \mathrm{~cm}$. from the rod. At $857 \mathrm{~mA}$ dc pump current applied to the diode array, the electrical input power was $1.6 \mathrm{~W}$ and the diode output power was 500 $\mathrm{mW}$. Under these conditions the TEM oo $\mathrm{CW}$ optical output power was 155 $\mathrm{mW}$ with the Ce,Nd:YAG rod but only $107 \mathrm{~mW}$ with the $N d: Y A G$ rod, which corresponds respectively to $9.5 \%$ and $6.6 \%$ electrical efficiency. The slope efficiency together with the optical and electrical efficiencies obtained with the two rods are summarized in table 1 . The results reported for the Ce,Nd:YAG rod are the highest obtained with a $500 \mathrm{~mW}$ laser diode $/ 1,2 /$. This rod being more effective, we used this rod to achieve mode-locked operation.

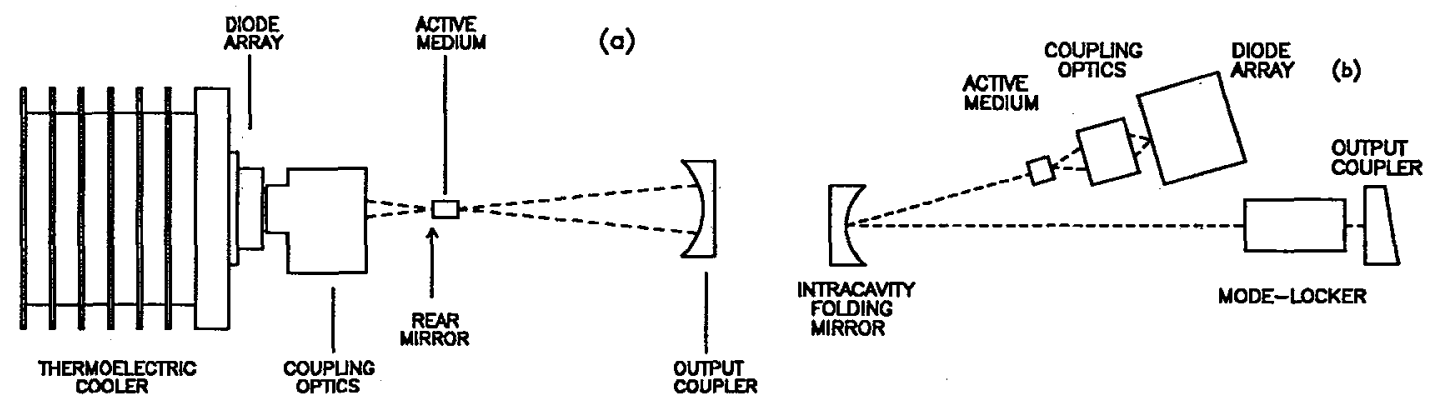

Fig.1 - Schematic diagrams of the short cavity setup (a) and extended cavity setup (b)

Table 1 : Performances of the short cavity setup

\begin{tabular}{|c|c|c|}
\hline ROD & Ce,Nd:YAG & Nd:YAG \\
\hline $\begin{array}{c}\text { SLOPE } \\
\text { EFFICIENCY }\end{array}$ & $34.7 \%$ & $24.4 \%$ \\
\hline $\begin{array}{c}\text { ELECTRICAL } \\
\text { EFFICIENCY }\end{array}$ & $9.5 \%$ & $6.6 \%$ \\
\hline $\begin{array}{c}\text { OPTICAL } \\
\text { EFFICIENCY* }\end{array}$ & $30.9 \%$ & $21.3 \%$ \\
\hline
\end{tabular}

*with $500 \mathrm{~mW}$ emitted from the diode 
In the extended cavity setup (fig.lb), an intracavity folding mirror of $15 \mathrm{~cm}$ radius of curvature produces an intracavity focus. The resonant cavity is completed by a plane output coupler of $10 \%$ transmission with a $10^{\circ}$ wedged rear surface. Mode-locking was accomplished using an acousto-optic mode-locker (IntraAction ML-53C) with a $1^{\circ}$ wedged rear surface placed close to the output coupler. It was either modified to operate at $95 \mathrm{MHz}$, either driven at the rated frequency of $53 \mathrm{MHz}$. The laser was frequency doubled using a crystal of potassium titanyl phosphate (KTP). The mode-locked system was optimized by use of. a fast photodiode and sampling oscilloscope and the pulses at $532 \mathrm{~nm}$ were analysed with a streak camera used in synchroscan mode and calibrated by mean of a pérot-Fabry interferometer. Figure 2 shows the curves recorded for a cavity length of $79 \mathrm{~cm}$ ( $\mathrm{fig.2a}$ ) or $140 \mathrm{~cm}$ (fig.2b) with $500 \mathrm{~mW}$ emitted from the diode. The best pulse durations were 133 ps and 149 ps full width at half maximum (FWHM) respectively at $190 \mathrm{MHz}$ and $106 \mathrm{MHz}$. The pulses should be compared with the predictions of the Kuizenga and siegman theory of mode-locking of homogeneously broadened lasers 13/. In this theory the pulse FWHM is proportional to $f^{-1 / 2}$ where $f_{m}$ is the drive frequency applied to the modulator. Thus, under the same experimental conditions but the modulation frequency being changed, the product $t_{p} f_{m}^{1 / 2}$, where $t_{p}$ is the pulse FWHM, should be constant. The results obtained for the two repetition rates are $1.1 \mathrm{ps}^{1 / 2}$ and $1.3 \mathrm{ps}^{1 / 2}$ respectively at $106 \mathrm{MHz}$ and $190 \mathrm{MHz}$, which indicates that the system has to be improved.
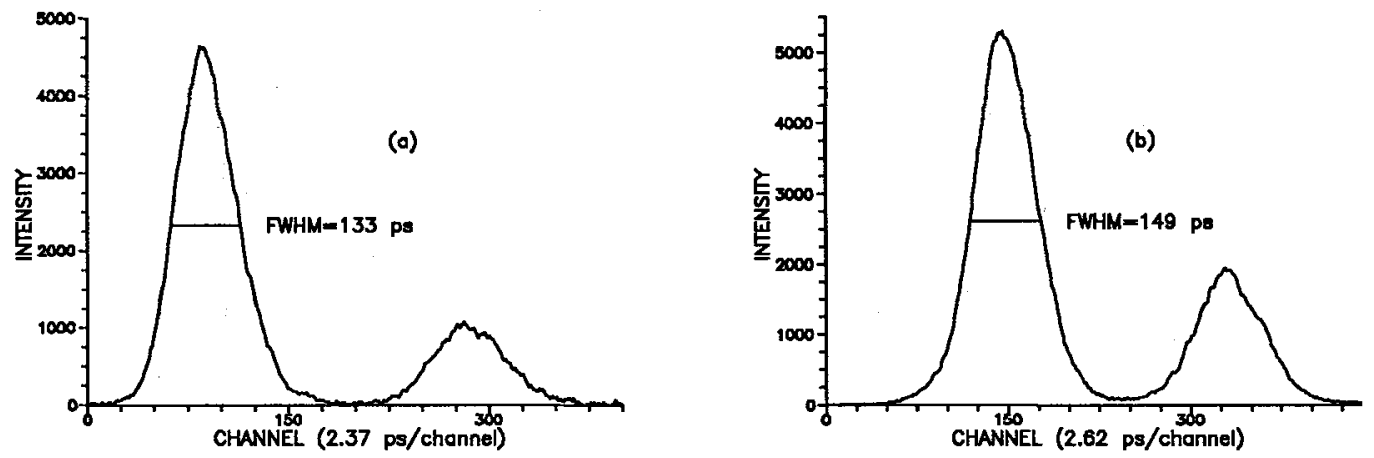

Fig.2 - Streak camera records at $190 \mathrm{MHz}$ (a) and $106 \mathrm{MHz}$ (b) 
In conclusion, mode-locked operation of a diode-pumped Ce,Nd:YAG laser has been achieved with pulse durations near 150ps. Further work is under way to optimize this device and upscale it to higher power levels.

\section{REFERENCES}

$/ 1 /$ BERGER J., WELCH D.F., SCIFRES D.R., STREIFER W., CROSS P.S., E1.Lett. 23(1987) 669 .

/2/ MAKER G.T., FERGUSON A.I., App 1.Phys.Lett. 55(1989) 525.

/3/ KUIZENZA D.J., SIEGMAN A.E., IEEE J. Quant.E1.QE-6(1970) 694 . 